Abstracta Iranica Abstracta Iranica

Revue bibliographique pour le domaine irano-aryen

Volume 27 | 2006

Comptes rendus des publications de 2004

Nal o Daman. Seyyed 'Alī Āl-e Dāvūd, éd., Tehrān, Markaz-e Našr-e Dānešgāhī 1107, adabīyāt-e fārsī 30, 1382/2003, 256 p. (incl. 16 p. ills.).

Anna Livia Beelaert

(2) OpenEdition

Journals

Édition électronique

URL : http://journals.openedition.org/abstractairanica/6402

DOI : 10.4000/abstractairanica.6402

ISSN : 1961-960X

Éditeur :

CNRS (UMR 7528 Mondes iraniens et indiens), Éditions de l'IFRI

Édition imprimée

Date de publication : 15 mai 2006

ISSN : 0240-8910

Référence électronique

Anna Livia Beelaert, « Nal o Daman. Seyyed 'Alī Āl-e Dāvūd, éd., Tehrān, Markaz-e Našr-e Dānešgāhī

1107, adabīyāt-e fārsī 30, 1382/2003, 256 p. (incl. 16 p. ills.). », Abstracta Iranica [En ligne], Volume 27 | 2006, document 305, mis en ligne le 02 janvier 2007, consulté le 25 septembre 2020. URL : http:// journals.openedition.org/abstractairanica/6402; DOI : https://doi.org/10.4000/abstractairanica.6402

Ce document a été généré automatiquement le 25 septembre 2020.

Tous droits réservés 


\title{
Nal o Daman. Seyyed 'Alī Āl-e Dāvūd, éd., Tehrān, Markaz-e Našr-e Dānešgāhī 1107, adabīyāt-e fārsī 30, 1382/2003, 256 p. (incl. 16 p. ills.).
}

\author{
Anna Livia Beelaert
}

1 En 1003/1594, une année avant sa mort prématurée à quarante-huit ans, Fayḍi composa à la demande du roi moghol Akbar ce matnavī qui aurait dû faire partie d'une Hamsa qui ne compterait jamais plus que trois œuvres. Celle-ci est la nazīire du Laylī o Majnūn de Nezāāī, et écrite dans le même mètre hazaj. L'histoire est tirée du Mahabhārata sanskrit.

2 Jusqu'ici le texte était difficilement accessible en quelques éditions lithographiées en Inde, et une édition non critique publiée à Téhéran en 1335/1956.

L'édition présente est pourvue d'une introduction sommaire (qui ne tient pas compte de recherches récentes, en particulier du livre important de G. Grobbel, Der Dichter Faidī und die Religion Akbars, de 2001) et d'une liste de vingt pages de mots et d'expressions considérés, parfois à tort, "nouveaux" (sans explication, mais avec une référence aux pages), utile pour un dictionnaire futur. Malheureusement, bien que précédée d'un liste de quarante-sept manuscrits, cette édition n'est pas critique non plus.

Comme texte de base Āl-e Dāvūd a choisi (sans argumentation) un manuscrit conservé à la bibliothèque du Majles à Téhéran (no. 9158), non daté, mais probablement du $11^{\mathrm{e}} / 17^{\mathrm{e}}$ s. Trois autres manuscrits, tous non datés, furent collationnés partiellement (ils sont conservés respectivement à la bibliothèque du Majles, à la bibliothèque de l'Université de Téhéran et à la bibliothèque Ganj BaHš̌ à Islamabad; Āl-e Dāvūd considère les deux derniers comme datant du $11^{\mathrm{e}} / 17^{\mathrm{e}} \mathrm{s}$.) ; enfin aussi une lithographie (Lucknow, 1930) a été consultée. Curieusement, Āl-e Dāvūd écrit (p. 38) s'être abstenu de mentionner les variantes parce qu'il y en avait trop. En effet, l'appareil critique est presque inexistant, ce qui est d'autant plus regrettable que déjà le nombre de vers - au dire de l'éditeur dans le relevé des manuscrits - est très variable (de moins de 3000 à plus de 4000 vers). Le travail reste donc encore à faire. 
5 Entretemps nous avons à notre disposition un texte à utiliser avec précaution, certes, mais qui néanmoins nous permet de juger des grandes différences entre l'histoire sanskrite originelle et le poème de Fayḍi, différences non pas tellement au niveau de l'intrigue, bien qu'il y en ait là aussi, mais au niveau de son interprétation. Il ne s'agit plus en premier lieu d'un hymne à un amour conjugal à toute épreuve, mais, par analogie au matnavi dont celui-ci est le pendant, d'un amour qui aboutit à la folie. Aussi ce poème mystique ne se termine-t-il pas avec l'heureuse réunion des protagonistes, mais avec leur immolation commune sur le bûcher, aspirant à une vérité au-delà du vaṣl et ferāq auxquels ils ont été soumis.

INDEX

Thèmes: 11.1.1. Littérature persane classique nompropre Nezāmi

\section{AUTEURS}

ANNA LIVIA BEELAERT

Université libre de Bruxelles 